\title{
PENGEMBANGAN SOAL HIGHER ORDER THINKING SKILLS BERBASIS BUDAYA JAWA TIMUR UNTUK MENGUKUR PENALARAN SISWA SD
}

\author{
Aina Lutfi Alfiatin', Wuli Oktiningrum² \\ Program Studi Pendidikan Guru SD Universitas Islam Raden Rahmat ${ }^{1,2}$ \\ ainalutfi563@gmail.com ${ }^{1}$ \\ wulie.okti@gmail.com²
}

\begin{abstract}
ABSTRAK
Penelitian ini bertujuan untuk menghasilkan soal matematika tipe HOTS yang valid dan praktis yang dapat digunakan untuk mengukur penalaran siswa. Pengembangan soal HOTS ini dibuat dengan menggunakan beberapa konteks budaya dari berbagai daerah Jawa Timur, diantaranya daerah Nganjuk, Jawa, Malang, dan Madura. Jenis penelitian yang digunakan adalah penelitian pengembangan. Model yang digunakan adalah model pengembangan tipe formative research Tessmer, yaitu preliminary dan tahap formative evaluation yang terdiri dari self evaluation, prototyping (expert review, one-to-one, dan small group), serta field test. Subjek pada one to one sebanyak 3 siswa kelas $\mathrm{V}$ Imam Bonjol, subjek pada small group sebanyak 6 siswa kelas V Imam Bonjol, dan subjek pada field test sebanyak 28 siswa kelas V Diponegoro SD Sunan Giri Ngebruk. Berdasarkan hasil penelitian, diperoleh instrumen tes yang valid, dengan kriteria tinggi yaitu 4,33 dan reliabel dengan kriteria tinggi yaitu nilai 0,85 . Hasil rata-rata tingkat kesukaran soal 0,67 dengan kategori sedang, dan hasil rata-rata daya pembeda 0,34 dengan kategori baik. Dari field test, hasil rata-rata kemampuan penalaran siswa 67,85 dengan kategori cukup., terdapat 7 siswa $(25 \%)$ memiliki kemampuan penalaran sangat baik, 7 siswa $(25 \%)$ memiliki kemampuan penalaran baik, 3 siswa $(10,71 \%)$ memiliki kemampuan penalaran cukup, dan 11 siswa $(39,29 \%)$ memiliki kemampuan penalaran kurang.
\end{abstract}

Kata kunci : pengembangan, soal tes, kemampuan penalaran

\begin{abstract}
This study aims to produce mathematical problems that are valid and practical HOTS types that can be used to measure student reasoning. The development of the HOTS question was made using several cultural contexts from various regions of East Java, including the Nganjuk, Java, Malang and Madura regions. This type of research used is development research. The model used is the Tessmer formative research type development model, which is the preliminary and formative evaluation stage which consists of self evaluation, prototyping (expert review, one-to-one, and small groups), and field tests. Subjects in one to one were 3 students in grade V Imam Bonjol, subjects in small group were 6 students in grade V Imam Bonjol, and subjects in the field test were 28 students in grade V Diponegoro SD Sunan Giri Ngebruk. Based on the results of the study, obtained a valid test instrument, with a high criterion of 4.33 and reliable with a high criterion of 0.85 . The average results of the level of difficulty of 0.67 in the medium category, and the average yield of 0.34 in the good
\end{abstract}


category. From the field test, the average results of students reasoning ability 67.85 with enough categories. There are 7 students $(25 \%)$ have very good reasoning abilities, 7 students $(25 \%)$ have good reasoning abilities, 3 students $(10.71 \%)$ have sufficient reasoning ability, and 11 students $(39.29 \%)$ have less reasoning ability.

Keywords : development, test questions, reasoning ability

\section{PENDAHULUAN}

Proses kognitif menurut Taksonomi Bloom yang telah direvisi terbagi menjadi dua, yaitu keterampilan berpikir tingkat tinggi atau biasa disebut dengan HOTS (Higher Order Thinking Skills) dan keterampilan berpikir tingkat rendah atau biasa disebut dengan LOTS (Lower Order Thinking Skills). Kemampuan berpikir tingkat rendah melibatkan kemampuan mengingat $(\mathrm{C} 1)$, memahami $(\mathrm{C} 2)$ dan menerapkan (C3). Sementara dalam kemampuan berpikir tingkat tinggi melibatkan analisis dan sintesis (C4), mengevaluasi (C5), dan mencipta atau kreativitas (C6) (Anderson and Krathworl, 2001: 66-68).

Keterampilan berpikir tingkat tinggi atau HOTS sangat penting dimiliki oleh siswa, karena keberhasilan dalam penguasaan suatu konsep akan didapatkan ketika siswa tidak hanya mengingat dan memahami suatu konsep, tetapi keberhasilan penguasaan suatu konsep dan pembelajaran dikatakan bermakna apabila siswa sudah mampu menganalisis serta mensintetis, mengevaluasi, dan mengkreasikan suatu konsep dengan baik (Laily, 2013:27-39).

Berdasarkan survey yang dilakukan oleh Organisation for Economic Cooperation and Development (OECD) menggunakan tes Programme Internationale for Student Assesment (PISA) tahun 2015, pendidikan di Indonesia menduduki ranking 69 dari 76 negara (Kemendikbud, 2016:2). Selain itu, hasil nilai Ujian Nasional siswa SD/MI tahun 2017 di Kabupaten Malang menempati peringkat 32 dari $38 \mathrm{kota} / \mathrm{kabupaten}$ se-Jawa Timur dengan hasil nilai rata-rata 6,8 seperti yang telah disampaikan oleh Sayekti, salah satu anggota Forum Masyarakat Peduli Pendidikan (FMPP) Kabupaten Malang pada tahun 2018. Hasil PISA dan Ujian Nasional tersebut rendah disebabkan soal yang diujikan termasuk soal-soal analisis (Samani, 2014:1). Soal analisis termasuk dalam kategori kemampuan berpikir tingkat tinggi atau Higher Order Thinking Skills (HOTS).

Sedangkan siswa dalam proses pembelajaran sehari-hari belum diajari pembelajaran yang bersifat HOTS dan juga belum pernah diberikan soal-soal tentang HOTS. Sehingga, pada saat diberikan soal mengenai HOTS siswa kesulitan untuk menjawabnya. Selain itu, menurut Dewi (2016:98-107) salah satu faktor yang menyebabkan kemampuan berpikirnya masih rendah adalah kurang terlatihnya anak Indonesia dalam menyelesaikan tes atau soal-soal yang sifatnya menuntut analisis, evaluasi, dan kreativitas yang tinggi.

Pemberian soal kepada siswa pun tidak boleh sembarangan. Pembuatan soal harus memperhatikan konten, konteks, dan bahasa yang baik. Salah satu syarat soal yang baik adalah soal yang kontekstual (Krathwohl, 2002). Dengan memberikan soal-soal yang kontekstual dan menarik dari permasalahan-permasalahan yang ada di sekitar seperti soal yang berbasis budaya yang ada di daerah, akan lebih membuat siswa tertarik dan juga memudahkan siswa untuk memahami dan menjawab 
pertanyaan tersebut, seperti yang telah dijelaskan oleh Sutarno (2012:147-152) bahwa dalam pembelajaran berbasis budaya sangat bermanfaat bagi pemaknaan proses dan hasil belajar bagi siswa untuk mendapatkan pengalaman belajar yang kontekstual dan bahan apersepsi untuk memahami konsep ilmu pengetahuan.

Tetapi hasil observasi lapangan yang dilakukan di SD Sunan Giri Ngebruk terhadap pembelajaran di kelas $\mathrm{V}$, menunjukkan bahwa guru dalam memberikan soal di kelas, masih memberikan soal yang monoton sehingga kemampuan siswa dalam berpikir tingkat tinggi masih tergolong rendah. Guru tidak membuat sendiri soal-soal yang diberikan kepada siswa, tetapi guru mengambil soal dari buku paket atau LKS tanpa mengembangkannya. Selain itu, guru juga kurang memperhatikan kriteriakriteria yang sesuai acuan dalam pembuatan soal dan juga soal yang dibuat lebih banyak menguji tentang aspek kognitifnya saja, masih banyak soal yang menuntut siswa untuk mengingat materi dibanding dengan memberikan soal yang menuntut siswa untuk berpikir kreatif. Sehingga pemahaman dan kemampuan penalaran siswa masih tergolong rendah karena kurangnya latihan soal-soal yang membuat siswa berpikir tingkat tinggi. Penalaran merupakan suatu kegiatan menarik kesimpulan dari pernyataan yang benar adanya yang sesuai dengan indikatornya yaitu mengajukan dugaan, manipulasi matematika, memberikan alasan, menarik kesimpulan, memeriksa kesahihan argumen, dan menemukan pola.

Berdasarkan permasalahan di atas, maka dilakukan penelitian pengembangan soal HOTS (Higher Order Thinking Skills) berbasis budaya Jawa Timur untuk mengukur penalaran siswa SD. Tujuan umum penelitian pengembangan ini adalah untuk menghasilkan soal HOTS yang valid dan praktis untuk mengukur penalaran siswa.

\section{METODE}

Jenis penelitian yang digunakan dalam penelitian ini adalah penelitian pengembangan (Research and Development). Sedangkan model yang digunakan dalam penelitian ini adalah model pengembangan tipe formative research Tessmer (1993:87). Model penelitian pengembangan ini meliputi tahap preliminary, self evaluation, prototyping (expert review dan one to one, small group), serta field test.

Penelitian ini dilaksanakan di SD Sunan Giri Ngebruk yang terletak di Kecamatan Sumberpucung Kabupaten Malang di kelas V pada semester genap 2018/2019. Subjek pada one to one sebanyak 3 siswa dari kelas V Imam Bonjol SD Sunan Giri Ngebruk. Subjek pada small group sebanyak 6 siswa dari kelas V Imam Bonjol SD Sunan Giri Ngebruk. Subjek pada field test semestinya sebanyak 32 siswa dari kelas V Diponegoro SD Sunan Giri Ngebruk, akan tetapi pada saat tes berlangsung dari 32 siswa terdapat 4 siswa yang tidak mengikuti, sehingga subjeknya hanya ada 28 siswa.

Prosedur penelitian pengembangan ini terdiri dari beberapa langkah, yaitu: 1) preliminary, 2) formative evaluation, 3) dan field test. Berikut ini adalah alur penelitian yang disajikan pada Gambar 1: 


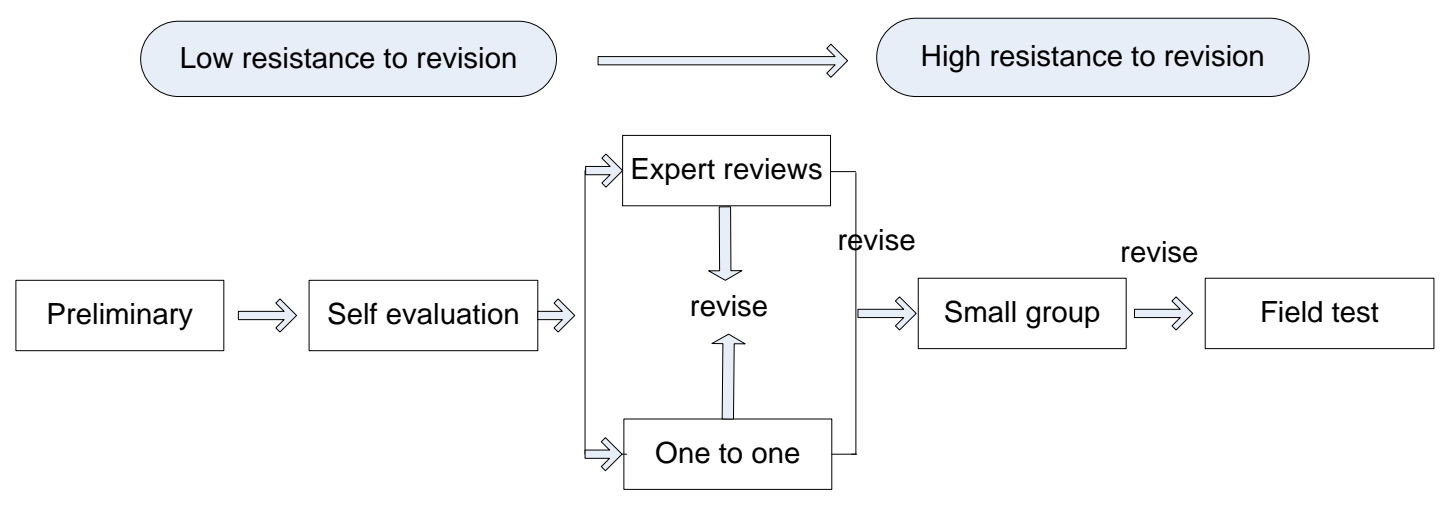

Gambar 1. Alur pengembangan Tessmer (1993)

Pada tahap preliminary, kegiatan yang dilakukan yaitu melakukan analisis persiapan dengan menentukan tempat dan subjek penelitian, serta melakukan wawancara terhadap guru bidang studi tentang pembelajaran di kelas sesuai dengan Kurikulum 2013. Tahap yang kedua yaitu tahap self evaluation, tahap ini meliputi dua tahap yaitu analisis dan desain. Pada tahap analisis terdiri dari analisis kurikulum, analisis siswa yang akan dijadikan subjek penelitian dan analisis materi yang akan digunakan dalam pembuatan soal, sedangkan pada tahap desain kegiatan yang dilakukan yaitu mendesain kisi-kisi, soal-soal dengan kemampuan penalaran berpikir tingkat tinggi dan juga kunci jawaban soal.

Produk yang sudah didesain akan dievaluasi pada tahap expert review, produk akan diujicobakan dalam 3 kelompok yaitu Expert review (pakar), One-to-one (siswa), dan Small group. Pada tahap expert review biasanya disebut dengan uji validitas, produk yang telah didesain akan dicermati, dinilai dan dievaluasi oleh pakar. Konten, konstruk, dan bahasa dari masing-masing prototif juga akan ditelaah oleh pakar, saran dari validator sebagai bahan untuk merevisi dan menyatakan bahwa instrumen soal telah valid. Tahap yang selanjutnya yaitu tahap one to one. Pada tahap ini, kegiatan yang dilakukan yaitu 3 orang siswa dengan kemampuan heterogen diminta untuk menjawab soal yang telah didesain dan ketiga siswa tersebut diminta berkomentar tentang soal. Berdasarkan komentar yang diperoleh akan digunakan untuk merevisi desain soal yang telah dibuat. Desain soal yang telah direvisi selanjutnya diujicobakan terhadap small group atau kelompok kecil, yang terdiri dari 6 siswa dengan kemampuan yang heterogen. Hasil pekerjaan dan komentar siswa terhadap soal pada tahap ini diharapkan menghasilkan instrumen tes yang mampu mengukur kemampuan penalaran berpikir tingkat tinggi. Tahap terakhir yaitu field test, pada tahap ini, hasil revisi yang diperoleh dari expert review, one to one, dan small group diujicobakan ke subjek penelitian yang lebih banyak, yakni siswa kelas V SD Sunan Giri Ngebruk yang berjumlah 28 siswa.

Instrumen yang digunakan dalam penelitian pengembangan ini berupa tes, lembar validasi, dan angket. Instrumen tes digunakan untuk memperoleh informasi mengenai kevalidan dan kepraktisan soal yang dikembangkan serta untuk mengetahui kemampuan penalaran siswa. Lembar validasi pada saat proses validasi oleh para ahli, sedangkan angket digunakan untuk memperoleh informasi dan komentar dari siswa untuk perbaikan soal. 


\section{HASIL DAN PEMBAHASAN}

Tahap Preliminary

Pada tahap ini kegiatan yang dilakukan yaitu pengumpulan beberapa referensi yang berkaitan dengan penelitian ini, yakni tentang penelitian pengembangan instrumen tes HOTS dan kemampuan penalaran siswa.

\section{Tahap Self Evaluation}

Pada tahap ini, yang dilakukan yaitu analisis terhadap siswa, kurikulum SD, dan juga materi apa saja yang digunakan dalam pengembangan soal. Setelah melakukan kegiatan analisis, tahap selanjutnya adalah mendesain atau merancang instrumen tes untuk mengukur kemampuan tingkat tinggi siswa pada aspek penalaran yang meliputi kisi-kisi tes, soal tes, kunci jawaban, dan pedoman penskoran. Soal dirancang sesuai dengan materi yang telah dianalisis dan indikator penalaran. Soal yang dirancang terdiri dari 6 soal uraian yang masing-masing terdapat kategori menganalisis, evaluasi, dan mencipta dan sesuai dengan indikator penalaran.

Tahap Prototyping

1) Expert review

Pada tahap ini, soal dievaluasi oleh validator dan saran dari validator digunakan sebagai bahan untuk merevisi dan menyempurnakan soal tes. Validator terdiri dari dua dosen matematika, yaitu Dyah Ayu Pramoda W., M.Pd selaku dosen Fakultas Psikologi dan Ilmu Pendidikan sebagai validator 1 dan Nanik Ulfa, M.Pd selaku dosen Fakultas Tarbiyah dan Keguruan sebagai validator 2, serta satu guru wali kelas V SD Sunan Giri Ngebruk yaitu Alfi Firdania F., S.Pd sebagai validator 3. Berdasarkan penilaian dari validator, penilaian umum yang diberikan dapat dilihat pada tabel di bawah ini :

Tabel 1. Penilaian umum validator

\begin{tabular}{cl}
\hline Validator & \multicolumn{1}{c}{ Penilaian umum validator } \\
\hline Validator 1 & $\begin{array}{l}\text { Instrumen tes dapat digunakan dengan sedikit revisi sesuai } \\
\text { dengan instruksi soal }\end{array}$ \\
Validator 2 & Instrumen tes dapat digunakan dengan sedikit revisi \\
Validator 3 & Instrumen tes dapat digunakan tanpa revisi \\
\hline
\end{tabular}

Berdasarkan Tabel 1 dapat diketahui penilaian umum dari validator seperti yang telah disebutkan. Walaupun demikian, masih dilakukan revisi pada prototif 1 atas dasar komentar dari para ahli.

\section{2) One to one}

Pada tahap ini, 3 siswa dengan kemampuan heterogen diminta untuk mengerjakan hasil prototif 1 . Ketiga siswa tersebut ialah FH, NK, dan YP. Selain diminta untuk mengerjakan soal, siswa juga diminta untuk mengomentari soal-soal yang telah dikerjakan. Berdasarkan angket yang telah diberikan kepada siswa, hasil yang didapat pada tahap ini adalah :

a. Soal nomor 2 pilihan jawabannya terlalu banyak.

b. Jumlah uang terlalu besar sehingga bingung untuk memilih.

c. Ada kalimat soal yang masih belum jelas, sehingga siswa bingung dengan maksud soal tersebut. 
Berdasarkan saran dan komentar dari pakar dan one to one yang telah diperoleh, maka soal-soal pada prototif 1 diperbaiki dan direvisi kembali, sehingga didapatkan prototif 2 hasil dari revisi prototif 1 .

\section{3) Small group}

Pada tahap ini, 6 siswa dengan kemampuan heterogen diminta untuk mengerjakan soal yang telah diberikan. Setelah mengerjakan soal tersebut, siswa diminta untuk memberikan komentar terhadap soal yang telah dikerjakan. Berdasarkan jawaban tes dan angket tersebut, pilihan jawaban soal nomor 2 terlalu banyak. Berdasarkan hasil pengerjaan dan komentar tersebut, soal direvisi dan dapat dilanjutkan ke tahap field test (uji coba lapangan).

Ujicoba produk dilakukan dengan menggunakan tes berupa soal uraian digunakan untuk mengetahui kemampuan penalaran siswa. Adapun peningkatan hasil pengembangan soal melalui indikator penalaran siswa, yaitu :

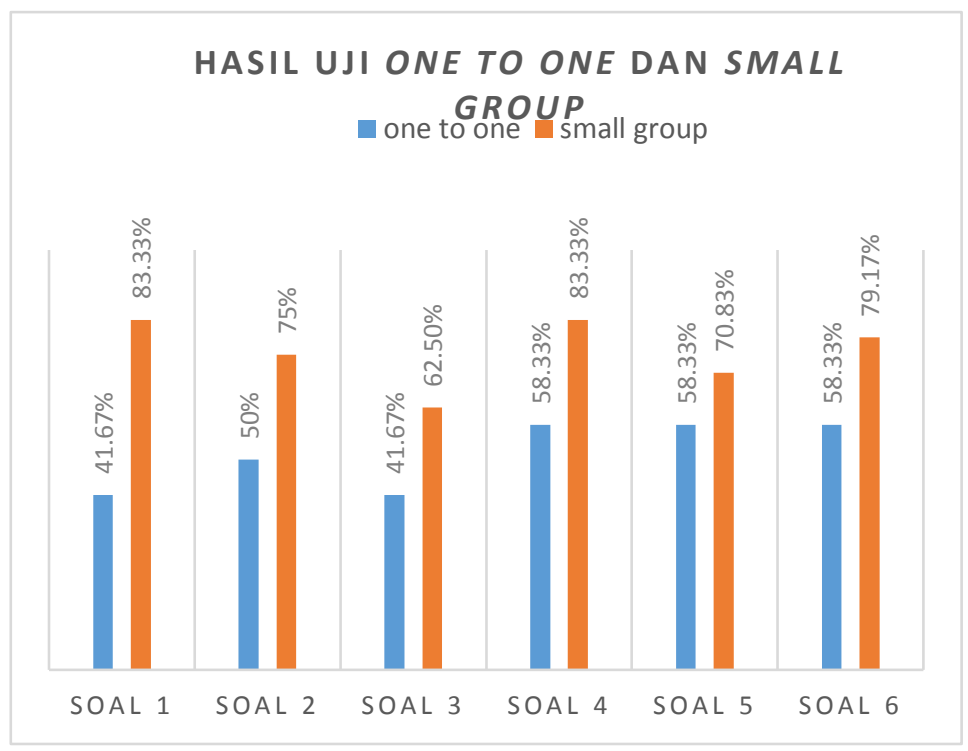

Grafik 1. Hasil uji one to one dan small group

Berdasarkan grafik di atas, dapat diketahui bahwa rata-rata hasil uji one to one yaitu 51,4, sedangkan uji small group pada aspek penalaran soal nomor 1 sampai 6 yaitu mendapatkan nilai rata-rata 75,7. Hal tersebut dapat menunjukkan bahwa adanya hasil pengembangan soal yang dapat mengukur penalaran siswa.

\section{Tahap Field Test}

Pada tahap ini, soal yang telah divalidasi dan direvisi diujicobakan pada siswa yang lebih banyak, yaitu siswa kelas V Diponegoro SD Sunan Giri Ngebruk. Siswa diminta untuk mengerjakan soal tes yang terdiri dari 6 butir soal uraian dengan alokasi waktu 2 × 35 menit. Hasil dari pekerjaan siswa kelas V Diponegoro SD Sunan Giri Ngebruk ini akan dianalisis untuk mengukur tingkat kemampuan penalaran siswa. Selain itu, hasil pekerjaan siswa akan dianalisis nilai realibilitas, tingkat kesukaran, serta daya pembeda instrumen tes yang dikembangkan. 
Hasil analisis data dari tes kemampuan berpikir tingkat tinggi tersebut dapat ditunjukkan pada tabel berikut :

Tabel 2. Hasil analisis tes kemampuan penalaran siswa

\begin{tabular}{|c|c|c|c|}
\hline Nilai siswa & Frekuensi & Persentase (\%) & Kategori \\
\hline $85<$ nilai $\leq 100$ & 7 & 25 & Sangat Baik \\
\hline $70<$ nilai $\leq 85$ & 7 & 25 & Baik \\
\hline $55<$ nilai $\leq 70$ & 3 & 10,71 & Cukup \\
\hline $40<$ nilai $\leq 55$ & 11 & 39,29 & Kurang \\
\hline $0<$ nilai $\leq 40$ & 0 & 0 & Sangat Kurang \\
\hline Jumlah subjek & 28 & $100 \%$ & \\
\hline Rata-rata Nilai & & & Cukup \\
\hline
\end{tabular}

Berdasarkan Tabel 2 tersebut, dapat diketahui bahwa dari 28 siswa, 7 siswa memiliki kemampuan dengan kategori sangat baik, 7 siswa memiliki kemampuan kategori baik, 3 siswa memiliki kemampuan dengan kategori cukup, dan 11 siswa memiliki kemampuan kurang. Instrumen tes tersebut dinyatakan efektif, karena ratarata nilai 67,85 dengan kategori cukup.

Arikunto (2010 : 211) menyatakan bahwa suatu tes dikatakan valid apabila tes

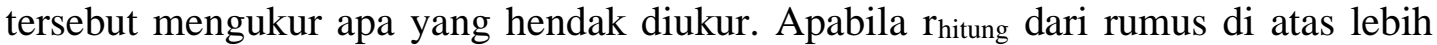
besar dari $\mathrm{r}_{\text {tabel }}$ maka butir tersebut valid, dan sebaliknya. Pada penelitian ini, validitas butir soal dilakukan dengan program pengolah data SPSS 18.

Tabel 3. Hasil validitas butir soal

\begin{tabular}{cccc}
\hline Butir Soal & $\mathrm{r}_{\text {tabel }}$ & $\mathrm{r}_{\text {hitung }}$ & Keterangan \\
\hline 1 & 0,361 & 0,729 & Valid \\
2 & 0,361 & 0,841 & Valid \\
3 & 0,361 & 0,784 & Valid \\
4 & 0,361 & 0,646 & Valid \\
5 & 0,361 & 0,813 & Valid \\
6 & 0,361 & 0,758 & Valid \\
\hline
\end{tabular}

Berdasarkan Tabel 3 dapat diketahui bahwa semua butir soal dinyatakan valid, karena nilai $r_{\text {hitung }}$ dari setiap butir soal lebih besar dari nilai $r_{\text {tabel. }}$.

Suatu instrumen penelitian dikatakan mempunyai nilai reliabilitas yang tinggi apabila tes yang dibuat mempunyai hasil yang konsisten dalam mengukur apa yang hendak diukur (Sukardi, 2014:127). Berdasarkan hasil uji lapangan di SD Sunan Giri Ngebruk kelas V Diponegoro dengan jumlah siswa yang mengikuti tes 28 siswa, dapat diketahui bahwa tingkat reliabilitas tes dari hasil pekerjaan siswa yaitu 0,85 dengan interpretasi reliabilitas tinggi.

Tingkat kesukaran butir item soal dikatakan baik apabila butir soal tidak terlalu sulit dan tidak terlalu mudah. Hasil analisis tingkat kesukaran tiap butir soal dapat dilihat pada tabel berikut : 
Tabel 4. Hasil analisis tingkat kesukaran

\begin{tabular}{ccc}
\hline Butir Soal & Tingkat kesukaran & Kategori \\
\hline 1 & 0,72 & Mudah \\
2 & 0,59 & Sedang \\
3 & 0,62 & Sedang \\
4 & 0,77 & Mudah \\
5 & 0,66 & Sedang \\
6 & 0,70 & Sedang \\
\hline
\end{tabular}

Berdasarkan Tabel 4 dapat diketahui bahwa dari 6 soal, soal nomor 2, 3, 5, dan 6 memiliki tingkat kesukaran sedang, artinya siswa seimbang antara yang menjawab salah dan yang menjawab benar. Sedangkan soal nomor 1 dan 4 memiliki tingkat kesukaran mudah, artinya banyak siswa yang menjawab soal tersebut dengan benar.

Butir soal dapat dikatakan baik apabila memiliki daya pembeda minimal 0,2 yang artinya cukup. Hasil analisis daya pembeda tiap butir item soal dapat dilihat pada tabel berikut:

Tabel 5. Hasil analisis daya pembeda

\begin{tabular}{ccc}
\hline Butir soal & Daya pembeda & Kategori \\
\hline 1 & 0,34 & Baik \\
2 & 0,42 & Baik \\
3 & 0,32 & Baik \\
4 & 0,3 & Baik \\
5 & 0,32 & Baik \\
6 & 0,32 & Baik \\
\hline
\end{tabular}

Berdasarkan Tabel 5 dapat diketahui bahwa soal nomor 1, 2, 3, 4, 5, dan 6 memiliki daya pembeda yang baik, artinya soal tersebut dapat membedakan kemampuan siswa yang berkemampuan tinggi dengan siswa yang berkemampuan rendah.

Berikut ini hasil nilai siswa pada tahap field test dalam mengerjakan soal HOTS, sesuai dengan indikator penalaran.

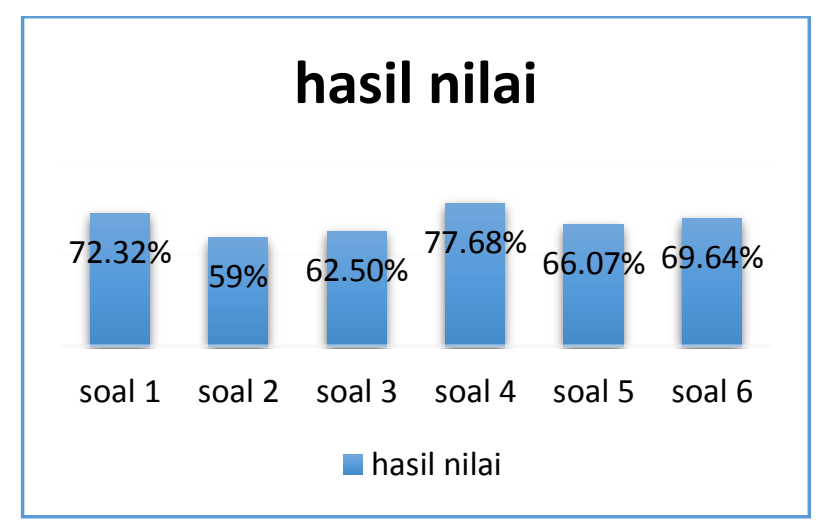

Grafik 2. Rata-rata hasil nilai siswa 
Berdasarkan Grafik 2 dapat diperoleh rata-rata tertinggi siswa terdapat pada soal ranah analisis dengan nilai $77,68 \%$, sedangkan rata-rata terendah terdapat pada soal ranah mencipta atau mengkreasi dengan nilai 59\%. Nilai rata-rata tertinggi terdapat pada soal ranah analisis dengan indikator menarik kesimpulan karena pada ranah tersebut siswa sudah mampu menentukan dan menggunakan berbagai cara dengan benar untuk mengetahui warna batik pada baris ke 132. Sedangkan nilai terendah terdapat pada soal ranah mencipta atau kreasi dengan indikator manipulasi matematika, karena masih banyak siswa yang masih belum tepat dalam memilih dan menghitung jumlah harga gamelan dengan menyisakan uang sesedikit mungkin. Kategori analisis ini termasuk dalam kategori gagal, karena masih banyak siswa yang belum memberikan jawaban yang tepat dan siswa belum mampu mencapai kategori analisis. Berikut ini hasil akhir 6 buah soal yang telah dikembangkan :

UNIT 1 Kesenian Wayang Timplong, Nganjuk, Jawa Timur

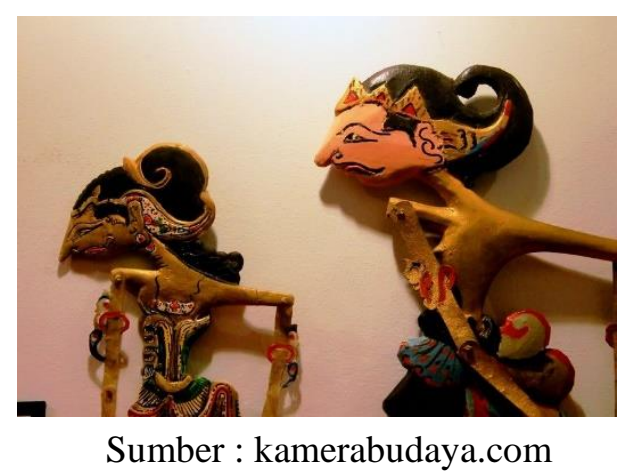

Wayang Timplong merupakan wayang yang terkenal di daerah Jawa Timur. Wayang Timplong sudah ada sejak tahun 1910-an di daerah Nganjuk. Wayang Timplong terbuat dari kayu pinus. Setiap harinya pengrajin dan para pekerjanya mampu membuat 325 wayang. Karena sekarang kayu pinus sudah langka, pengrajin hanya mampu membuat $\frac{2}{5}$ dari hasil biasanya. Jika setiap kotak yang berisi 60 wayang dapat menghasilkan Rp 18.000.000. Berapa besar penghasilan yang diperoleh sesudah kayu pinus langka? Berikan pendapatmu!

UNIT 2 Alat Musik Gamelan, Jawa

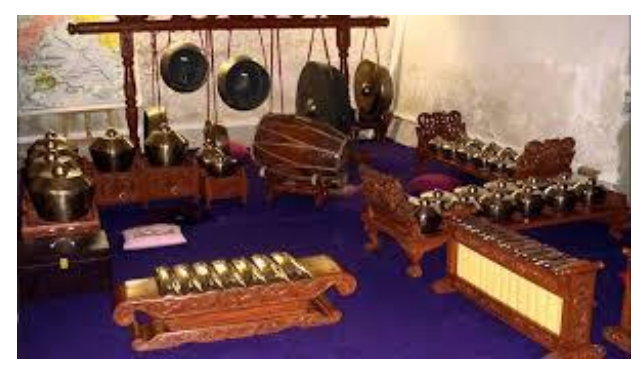

Sumber : budayajawa.id 
Daftar harga seperangkat alat musik gamelan

\begin{tabular}{llc}
\multicolumn{2}{c}{ "TOKO SERBA ADA" } \\
\hline \multicolumn{1}{c}{ Nama barang } & Harga \\
\hline Kendang ketipung & $\mathrm{Rp} \quad 400.000,00$ \\
Kendang kempul & $\mathrm{Rp} 1.500 .000,00$ \\
Kendang jaipong & $\mathrm{Rp} 1.750 .000,00$ \\
\hline Gambang & $\mathrm{Rp} \quad 750.000,00$ \\
Gambang lenong & $\mathrm{Rp} 1.950 .000,00$ \\
Gambang jawa laras & $\mathrm{Rp} 3.500 .000,00$ \\
\hline Bonang perunggu & $\mathrm{Rp} 950.000,00$ \\
Bonang kuningan & $\mathrm{Rp} \quad 630.000,00$ \\
Bonang besi & $\mathrm{Rp} 150.000,00$ \\
\hline
\end{tabular}

Pak Ahmad akan membeli beberapa alat musik gamelan di Toko Serba Ada. Pak Ahmad mempunyai uang Rp 4.120.000,00. Dengan daftar harga yang ada, alat musik yang mana saja yang dapat dibeli oleh pak Ahmad dengan uang Rp 4.120.000,00 dengan syarat wajib membeli kendang, gambang, dan bonang dan uang yang tersisa sesedikit mungkin? Berikan pendapatmu !

\section{UNIT 3 Tari Wayang Topeng Malangan}

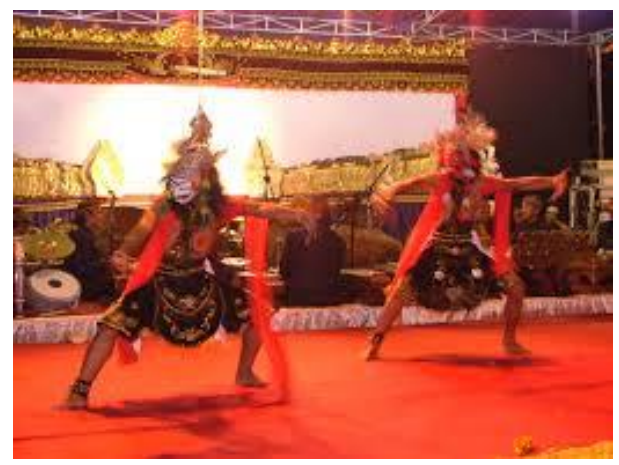

Sumber : vinashafa.blogspot.com

Tari wayang Topeng Malangan dikenal juga dengan sebutan Tari Bapeng. Tari wayang topeng merupakan sebuah tarian khas Malang yang pemerannya semua menggunakan topeng. Harga tiket masuk untuk melihat pertunjukan tari wayang topeng yaitu $\mathrm{Rp} 25.000,00$ untuk pengunjung domestik atau pengunjung dalam negeri dan $\mathrm{Rp} 100.000,00$ untuk pengunjung mancanegara. Di antara 16 pengunjung yang datang, ada beberapa pengunjung dari mancanegara. Jika penghasilan yang diperoleh panitia Rp 850.000,00, tentukan pernyataan di bawah ini yang bernilai benar atau salah dan berikan alasanmu !

\begin{tabular}{l|l}
\hline Tiket pengunjung domestik yang telah terjual 2 tiket lebih & Benar / Salah \\
sedikit dari dua kali banyak tiket macanegara yang terjual. & \\
\hline $\begin{array}{l}\text { Jumlah pengunjung yang datang ke pertunjukan lebih } \\
\text { banyak pengunjung mancanegara daripada pengunjung } \\
\text { domestik. }\end{array}$ & \\
\hline
\end{tabular}




\section{UNIT 4 Batik Madura, Jawa Timur}

Batik Madura termasuk batik yang mempunyai motif cukup beragam dengan warna yang lebih berani dan mempunyai beberapa keunikan dan keindahan motif batik yang populer, sehingga menjadi kebanggaan wilayah tersebut. Salah satunya yaitu adalah batik Madura dari Bangkalan.

Perhatikan motif batik Madura di bawah ini.

baris ke 1

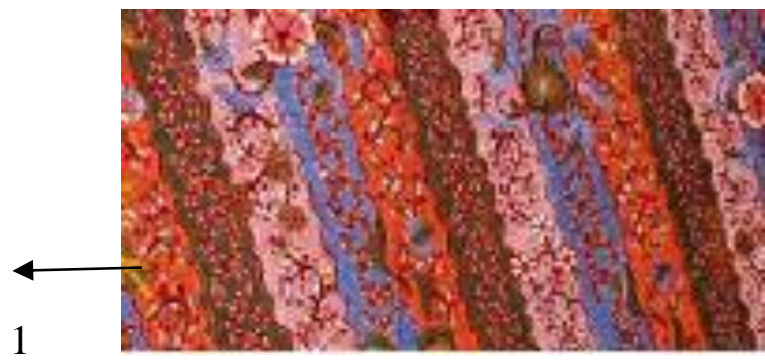

Sumber : madurabatik.com

Tentukan motif batik pada baris ke 132 ! Berikan pendapatmu !

UNIT 5 Candi Jago, Malang, Jawa Timur

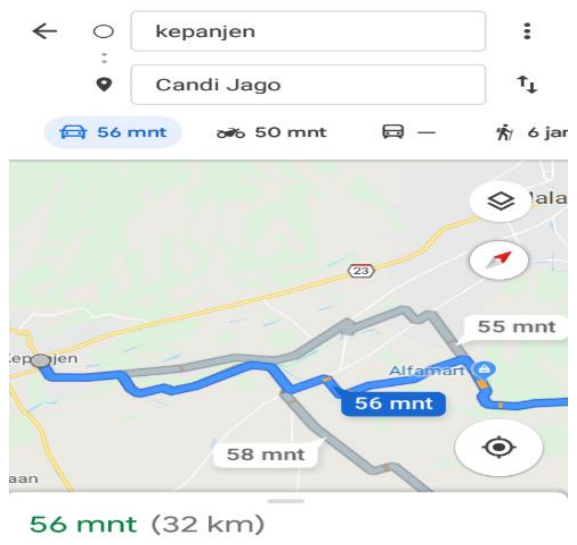

Sumber : maps Kepanjen-Candi Jago

Gambar 1. Rumah Ana

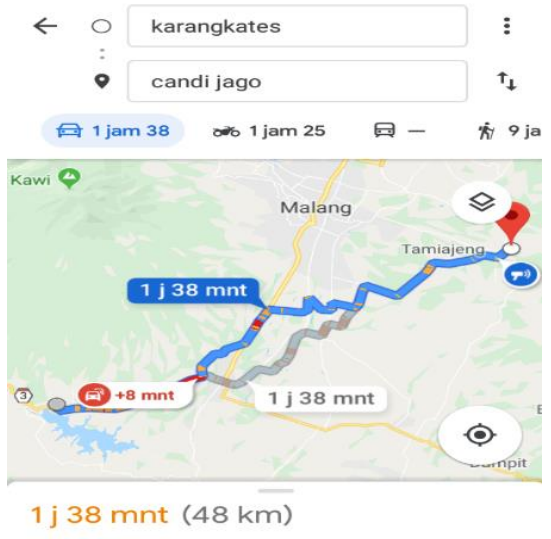

Sumber : maps Karangkates Candi Jago

Gambar 2. Rumah Ahmad

Ana dan teman-temannya yaitu Ahmad, Ani, Harun, Dani, dan Mawar akan pergi ke Candi Jago untuk mengerjakan tugas sekolah yaitu mengamati bentuk Candi Jago dan sejarah dari Candi Jago. Mereka akan pergi dengan mengendarai mobil. Jarak Rumah Ana dari Kepanjen menuju ke Candi Jago adalah 32 km. Sedangkan jarak rumah Ahmad ke Candi Jago adalah 48 km. 
Berikut ini mobil yang dapat dipilih oleh Ana dan teman-temannya.

\begin{tabular}{cccccc}
\hline No & $\begin{array}{c}\text { Jenis } \\
\text { kendaraan }\end{array}$ & $\begin{array}{c}\text { Konsumsi } \\
\text { BBM }\end{array}$ & $\begin{array}{c}\text { Kapasitas } \\
\text { tangki }\end{array}$ & $\begin{array}{c}\text { Biaya sewa } \\
\text { sopir }\end{array}$ & $\begin{array}{c}\text { Harga perliter } \\
\text { bensin }\end{array}$ \\
\hline 1 & Mobil Ana & $8 \mathrm{~km} /$ liter & 45 liter & Rp 75.000,00 & Rp 11.000,00 \\
2 & $\begin{array}{c}\text { Mobil } \\
\text { Ahmad }\end{array}$ & $16 \mathrm{~km} /$ liter & 33 liter & Rp 100.000,00 & Rp 11.000,00 \\
& & & & \\
\hline
\end{tabular}

*dengan posisi awal tangki mobil kosong

Kecepatan rata-rata mobil Ana menuju Candi Jago adalah 34,41 km/jam. Sedangkan waktu yang dibutuhkan mobil Ahmad untuk sampai di Candi Jago adalah 98 menit. Coba bantulah Ana dan teman-temannya untuk memilih mobil mana yang harus dipilih dengan biaya yang paling murah dan waktu yang tersingkat dalam menempuh perjalanan. Berikan pendapatmu!.

UNIT 6 Candi Singosari, Malang, Jawa Timur

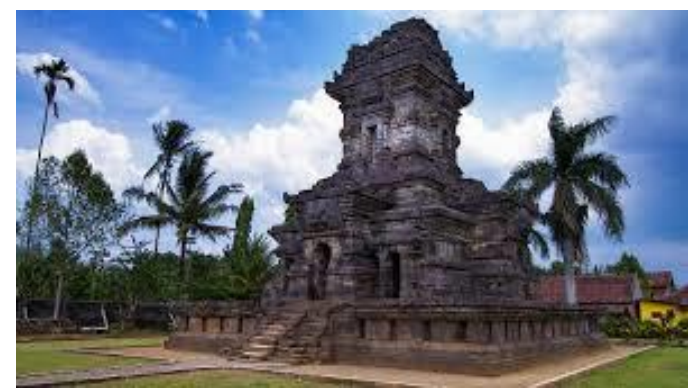

Sumber : jejakpiknik.com

Candi Singosari mempunyai alas yang berbentuk persegi 14 x 14 meter dengan bangunan candi yang menjulang 15 meter. Untuk melestarikan dan melindungi Candi Singosari dari kerusakan, Pemerintah Kabupaten Malang akan memasang pagar besi yang akan mengelilingi Candi Singosari dengan tinggi pagar 7 meter serta menanam bunga yang mengelilingi candi untuk memperindah sekelilingnya. Di bawah ini tabel harga macam-macam pagar dan biaya yang dikeluarkan.

\begin{tabular}{lll}
\hline \multicolumn{1}{c}{ Macam-macam pagar } & \multicolumn{1}{c}{ Jarak } & \multicolumn{1}{c}{ Harga/meter ${ }^{2}$} \\
\hline Hollow besi biasa & Jarak 8-10 cm & Rp 390.000,00 \\
Hollow besi biasa & Jarak 5-7 cm & Rp 480.000,00 \\
Hollow besi biasa & Jarak 3-4 cm & Rp 550.000,00 \\
Hollow galvanis anti karat & Jarak 8-10 cm & Rp 450.000,00 \\
Hollow galvanis anti karat & Jarak 5-7 cm & Rp 575.000,00 \\
Hollow galvanis anti karat & Jarak 3-4 cm & Rp 580.000,00 \\
Besi tempa anti karat & Permeter & Rp 595.000,00 \\
\hline
\end{tabular}


Harga setiap tanaman bunga yaitu Rp 7.000,00. Jika untuk membangun pagar dan membeli tanaman diberikan anggaran Rp 33.000.000,00, tentukan pagar mana yang dapat dipilih untuk melindungi candi dengan ketentuan pagar yang akan dipilih anti karat, dan berapa tanaman bunga yang dibutuhkan untuk ditanam mengelilingi candi yang setiap bunga berjarak $1 / 2$ meter, dengan menyisakan uang anggaran paling minim ! Berikan alasanmu!

Instrumen dinyatakan valid, ditunjukkan dengan adanya hasil penilaian dari validator pada tahap expert review yang menyatakan semua butir soal valid, soal sudah sesuai dengan karakteristik HOTS, dan soal sudah cukup memenuhi enam langkah indikator penalaran yaitu: 1) mengajukan dugaan, 2) manipulasi matematika, 3) memberikan alasan, 4) menarik kesimpulan, 5) memeriksa kesahihan argumen, 6) menemukan pola. Instrumen juga dinyatakan praktis, karena mudah dilaksanakan dan mudah diperiksa karena disertai dengan petunjuk-petunjuk yang jelas.

\section{SIMPULAN DAN SARAN}

Berdasarkan hasil analisis validitas, reliabilitas, dan juga kemampuan penalaran siswa yang telah dikembangkan, soal dikategorikan valid dan reliabel. Hal tersebut didapatkan dari hasil analisis validitas 4,33 dengan interpretasi tinggi. Hasil analisis reliabilitas sebesar 0,85 dengan interpretasi tinggi. Hasil analisis tingkat kesukaran didapatkan 4 soal dengan interpretasi sedang dan 2 soal dengan interpretasi mudah. Hasil analisis daya pembeda didapatkan 6 soal dengan interpretasi baik. Serta berdasarkan hasil analisis kemampuan penalaran siswa, nilai rata-rata 67,85 dalam kategori baik.

Soal HOTS berbasis Budaya Jawa Timur yang meliputi daerah Jawa, Malang, Nganjuk, dan Madura sudah mencapai indikator dengan baik, dibuktikan dengan nilai rata-rata tertinggi pada ranah analisis dengan indikator menarik kesimpulan dengan nilai $77,68 \%$ dan nilai rata-rata terendah terdapat pada ranah mencipta dengan indikator manipulasi matematika dengan nilai $59 \%$.

\section{DAFTAR PUSTAKA}

Anderson, L.W., and Krathwohl, D.R. 2001. A Taxonomy for Learning, Teaching, and Assesing; A revision of Bloom's Taxonomy of Education Objectives. New York: Addison Wesley Lonman Inc.

Arikunto, Suharsimi. 2010. Prosedur Penelitian Suatu Pendekatan Praktik. Jakarta: Rineka Cipta.

Dewi, Nastitisari. 2016. Analisis Kemampuan Berpikir Kompleks Siswa Melalui Pembelajaran Berbasis Masalah Berbantuan Mind Mapping. Jurnal Edu Sains, Vol 8(1) : 99-107. [Online]. Tersedia: http://journal.uinjkt. ac.id/index. php/ edusains. [20 Oktober 2018].

Kemendikbud. 2016. Hasil Survei PISA Peningkatan Capaian Indonesia termasuk Empat Besar. Kementerian Pendidikan dan Kebudayaan Badan Penelitian dan Pengembangan. [Online]. Tersedia: http://kemdikbud.go.id. [19 Oktober 2018].

Krathwohl. 2002. A Revision of Bloom's Taxonomy: An Overview. College of Education. The Ohio State University. 
Laily, Nur Rochmah. 2013. Analisis Soal Tipe Higher Order Thinking Skill (HOTS) Dalam Soal UN Kimia SMA Rayon B Tahun 2012/2013. Jurnal Kaunia, Vol. 9(1) : 27-39. [Online]. Tersedia: http://jurnal.unswagati.ac.id/index.php /Euclid/article /download/323/203. [19 Oktober 2018].

Samani, Muchlas. 2014. Siswa Kita Jeblog di PISA, Mengapa?. [Online]. Tersedia: http://eksis.ditpsmk.net/artikel/siswa-kita-jeblok-di-pisa-mengapa. [20 Oktober 2018].

Sukardi. 2014. Metodologi Penelitian Pendidikan. Yogyakarta: Bumi Aksara.

Sutarno. 2012. Serba-serbi Manajemen Bisnis. Yogyakarta: Graha Ilmu.

Tessmer, Martin. 1993. Planning and Conducting Formative Evaluations: Improving the Quality of Education and Training. London: Kogan. 